\title{
An Added Value Analysis of Chicken Meat Products at PT. Sierad Produce Tbk
}

\author{
Akhmad Mahbubi $^{a^{*}}$, Acep Muhib $^{\mathrm{b}}$, Denanda Putri ${ }^{\mathrm{c}}$ \\ ${ }^{a, b, c}$ Department of Agribusiness \\ Syarif Hidayatullah State Islamic University Jakarta \\ Tangerang Selatan, Indonesia \\ *Email: akhmad.mahbubi@uinjkt.ac.id
}

\begin{abstract}
An added value analysis was performed on 16 processed chicken products, consisting of 11 types of Chicken Nugget products, 2 types of meatball products, Chicken Golden Fillet, Fried Chicken, and Spicy Wing. By employing Hayami method, we find the added value of 16 processed chicken products at PT Sierad Produce Tbk has an average added value of $\mathrm{Rp}$. 38.041. The value represents the gross profit earned from processing chicken meat into processed chicken products of Rp. 38,041 per kilogram. The value of the margin distribution of processed chicken products is Rp. 40,864 per kilogram. This value indicates the contribution of owners factors in processing chicken meat into processed chicken products. The profit rate obtained by PT Sierad Produce Tbk from processing chicken meat into processed chicken products amounted to $67.55 \%$. The value is a net added value of the process of processing chicken meat into processed chicken products.
\end{abstract}

Keywords : Added value, Hayami, Processed chicken products

\section{Introduction}

Chicken meat plays a big role in meeting the food needs of the people in Indonesia. In the period of 2012 2014 chicken meat consumption of the community has increased followed by the number of population and broiler production. This increase is not limited to raw meat alone, but also in processed form [1]. This is because processed products have higher selling prices and added value compared to raw chicken products. One of the companies that process raw chicken meats into processed chickens is PT. Sierad Produce Tbk through its subsidiary of PT. Belfoods Indonesia. Although PT Sierad Produce has been able and produces many processed chicken products, the company still needs value-added analysis to investigate the added value created for each product as well as the profit obtained by the company. Therefore, the purpose of this study is: 1) to analyze the value added by the processed chicken products of PT Sierad Produce Tbk, 2) to analyze the distribution of the margin of processed chicken products at PT Sierad Produce Tbk, and 3) to analyze the profit level gained by PT Sierad Produce Tbk from processed chicken meat production. Beberapa penelitian sebelumnya telah menganalisis value added dari komoditas pangan [2], [3], [4], [5]. The results of this study are expected to enrich the knowledge, especially about the value-added from poultry products.

\section{Research Method}

The method employed in this study is value-added analysis. Moreover, Hayami method is employed as the analytical tool to calculate the added value, margin distribution, and profitability of the processed products at PT Sierad Produce Tbk (Table 1).

\begin{tabular}{|c|c|}
\hline Variables & Values \\
\hline \multicolumn{2}{|l|}{ Output, input, and prices } \\
\hline 1. Output & $\mathrm{A}$ \\
\hline 2. Raw material & $\mathrm{B}$ \\
\hline 3. Labor & $\mathrm{C}$ \\
\hline 4 Conversion factor & $\mathrm{D}=\mathrm{A} / \mathrm{B}$ \\
\hline 5. Labor coefficient & $\mathrm{E}=\mathrm{C} / \mathrm{B}$ \\
\hline 6. Output price & $\mathrm{F}$ \\
\hline 7 Average wage & $\mathrm{G}$ \\
\hline \multicolumn{2}{|l|}{ Revenue and profit } \\
\hline 8. Raw material price & $\mathrm{H}$ \\
\hline 9. Other input price & I \\
\hline 10. Output value & $\mathrm{J}=\mathrm{DX} \mathrm{F}$ \\
\hline 11. a. Added value & $\mathrm{K}=\mathrm{J}-\mathrm{H}-\mathrm{I}$ \\
\hline b. Output value ratio & $\mathrm{L} \%=((\mathrm{K} / \mathrm{J}) \times 100 \%)$ \\
\hline 12. a. Labor revenue & $\mathrm{M}=\mathrm{ExG}$ \\
\hline b. Labor portion & $\mathrm{N} \%=((\mathrm{M} / \mathrm{K}) \times 100 \%)$ \\
\hline 13. a. Profit & $\mathrm{O}=\mathrm{K}-\mathrm{M}$ \\
\hline b. Profit rate & $\mathrm{P} \%=((\mathrm{O} / \mathrm{J}) \times 100 \%)$ \\
\hline \multicolumn{2}{|l|}{$\begin{array}{l}\text { Owner of factor } \\
\text { production repayment }\end{array}$} \\
\hline 14. Margin & $\mathrm{Q}=\mathrm{J}-\mathrm{H}$ \\
\hline a. Labor revenue & $\mathrm{R} \%=((\mathrm{M} / \mathrm{Q}) \times 100 \%)$ \\
\hline $\begin{array}{ll}\text { b. Other inputs } \\
\text { contribution }\end{array}$ & $\mathrm{S} \%=((\mathrm{I} / \mathrm{Q}) \times 100 \%)$ \\
\hline c. Company profit & $\mathrm{T} \%=((\mathrm{O} / \mathrm{Q}) \times 100 \%)$ \\
\hline
\end{tabular}

Source: [6]

\section{Results And Discussion}

Chicken is the main raw material used in processing at PT Sierad Produce Tbk. The products that have undergone such processing have a higher price than the previous products that have not experienced the processing. The products to be analyzed for added value consist of Chicken 
Nuggets (Chicken Nugget Ceria, Chicken Nugget Safari, Chicken Nugget S Royal, Chicken Nugget S Uenaaak, Favorite Chicken Nugget, Chicken Nugget Uenaaak, Chicken Nugget Stick Royal, Chicken Nugget Stick Favorite, Chicken Nugget Stick Uenaaak, Chicken Nugget Number, Chicken Nugget Drummies), Chicken Fillet, Fried Chicken, Spicy Wing, and Meatballs (Fried Meatballs and Chicken Meatballs).

\subsection{Added Value of Processed Chicken Products}

Each processed chicken product produced by PT Sierad Produce has various added value. Chicken Nugget products have an added value of Rp 32,537 per kilogram of raw material and has a percentage of the output value of $39.85 \%$. Golden Fillet Chicken products have added value of $\mathrm{Rp} 81,911$ per kilogram with the added value percentage of $65.31 \%$ of the output value. Fried Chicken products have an added value of $\mathrm{Rp} 44,322$ per kilogram with a percentage of $60.95 \%$ of the value of its output. Spicy Wing has an added value of Rp 21,915 per kilogram and has a percentage of added value of $30.58 \%$. Meatballs produce added value of $\mathrm{Rp} 9,519$ per kilogram with the added value ratio of $23.07 \%$. When the five products are averaged, the added value of processed chicken products produced by PT Sierad Produce Tbk is Rp 38,041 per kilogram, which means the processing of each kilogram of chicken meat into Chicken Nugget, Chicken Golden Fillet, Fried Chicken, Spicy Wing and Bakso products gives a gross profit of $\mathrm{Rp} 38,041$ per kilogram. The average valueadded ratio of these products amounted to $43.95 \%$, which means the average output value of $\mathrm{Rp} 77,800$, amounting to $43.95 \%$ is part of the added value. Value added products are low because the resulting value is smaller than the value of output.

Of the 16 types of products produced by the company, there are 5 products that have the highest added value. Processed chicken products with high added value are Chicken Golden Fillet, Chicken Nugget Ceria, Chicken Nugget Safari, Chicken Nugget Stick Royal and Chicken Nugget S Royal. Each product has a different value added. Chicken Golden Fillet has an added value of Rp 81,911 per kilogram, Chicken Nugget Ceria Rp 56,566 per kilogram, Chicken Nugget Safari Rp 51,906 per kilogram, Chicken Nugget Stick Royal Rp 50,262 per kilogram, and Chicken Nugget S Royal Rp 47,320 per kilogram. Of the five products, Chicken Golden Fillet is the highest valueadded product, which is $\mathrm{Rp} 81,911$ per kilogram. This indicates that Chicken Golden Fillet is a superior product due to a low production cost. In addition the conversion factor, the price of Chicken Golden Fillet products are high. The conversion factor has a value of $1,55 \mathrm{~kg}$ and the product selling price is $\mathrm{Rp} 81,093$ per kilogram. Since both are multiplied, then it will result in a large output value. When aside from the price of production and the price of raw materials, it will be obtained a large added value. Processed add-on products consist of 6 products, including Fried Chicken, Chicken Nugget Drummies, Chicken Nugget Favorite, Chicken Nugget Stick Favorite, Chicken Nugget Number, and Spicy Wing. Fried Chicken has an added value of Rp 44,322 per kilogram, Chicken Nugget
Drummies has an added value of Rp 44,150 per kilogram, Chicken Nugget Favorite has an added value of Rp 30,865 per kilogram, Chicken Nugget Stick Favorite has an added value of Rp 27,821, Chicken Nugget Number has an added value of $R p$ 26,437, and Spicy Wing has an added value of Rp 21,915 per kilogram. The added value of these products is fairly moderate because of the amount of other input costs and raw material costs that are neither too high nor low of the output value.

The products that have the lowest added value are Chicken Nugget S Uenaaak, Chicken Meatballs, Chicken Nugget Stick Uenaaak, Chicken Nugget Uenaaak, and Bakso Goreng. Chicken Nugget S Uenaaak products are processed chicken products with the lowest added value, which is Rp 4,236 per kilogram, which means the product gives a gross profit of Rp 4,236 per kilogram. This is because input prices and other input prices are high. When the value of ouput is subtracted by input prices and other input prices will result in a low added value.

\subsection{Chicken Nugget Margin Distribution}

The margin distribution value of 16 processed chicken products is $\mathrm{Rp} 40,864$ per kilogram. The value is the average margin of Chicken Nugget, Chicken Golden Fillet, Fried Chicken, Spicy Wing and Meatball products. Chicken Nugget has an average value of Rp 33,795 per kilogram, Chicken Golden Fillet of Rp 84,952 per kilogram, Fried Chicken of Rp 45,265 per kilogram, Spicy Wing of Rp 23,218 per kilogram, and Meatballs have an average value margin of $\mathrm{Rp} 17,092$ per kilogram. The average margin value of 16 types of products will be distributed to labor, other inputs, and corporate profits. Employee benefits absorb 22,5\%, other inputs absorb by $9,95 \%$, and profit equal to $67,65 \%$.

\subsection{Profit rate}

PT Sierad Produce gained an average profit rate of $67,55 \%$ from processing chicken meat to processed chicken products. The value is the average profit gained from Chicken Nugget, Chicken Golden Fillet, Fried Chicken, Spicy Wing, and Meatball products. Eleven Chicken Nugget products provide a 88,26\% profit, Chicken Golden Fillet provides a $79,72 \%$ profit, Fried Chicken provides a $88,2 \%$ profit, Spicy Wing provides a $63,22 \%$ profit, and both products of Meatballs provide a $18.35 \%$ profit for the company (Table 2 ).

Table 2. Profit Rate of Processed Chicken Products

\begin{tabular}{|l|l|l|}
\hline No & Products & $\%$ \\
\hline 1 & Chicken Nugget Ceria & 98,21 \\
\hline 2 & Chicken Nugget Safari & 95,97 \\
\hline 3 & Chicken Nugget S Royal & 97,45 \\
\hline 4 & Chicken Nugget S Uenaaak & 64,9 \\
\hline 5 & Chicken Nugget Favorite & 96,9 \\
\hline 6 & Chicken Nugget Uenaaak & 94,02 \\
\hline 7 & Chicken Nugget Stick Royal & 94,51 \\
\hline
\end{tabular}


Table 2. Profit Rate of Processed Chicken Products (Cont.)

\begin{tabular}{|c|l|r|}
\hline 8 & Chicken Nugget Stick Favorite & $\mathbf{9 5 , 9 3}$ \\
\hline 9 & Chicken Nugget Stick Uenaaak & 57,8 \\
\hline 10 & Chicken Nugget Number & 81,85 \\
\hline 11 & Chicken Nugget Drummies & 93,33 \\
\hline 12 & Chicken Golden Fillet & 79,72 \\
\hline 13 & Fried Chicken & 88,2 \\
\hline 14 & Spicy Wing & 63,22 \\
\hline 15 & Fried Chicken Meatballs & $-34,2$ \\
\hline 16 & Chicken Meatballs & 70,91 \\
\hline
\end{tabular}

Source: Processed Data (2016)

\section{Conclusion and Recommendation}

\subsection{Conclusion}

Based on the results of value added analysis of processed chicken products from PT Sierad Produce Tbk, it can be concluded as follows:

1. The added value of 16 processed chicken products at PT Sierad Produce Tbk is Rp 38,041 per kilogram. The value represents the gross profit earned from processing chicken meat into processed chicken products.

2. The 16 processed products of PT Sierad Produce Tbk have a margin distribution value of $\mathrm{Rp} 40,864$ per kilogram. This value indicates the contribution of owners factors in processing chicken meat into processed chicken products.

3. The profit rate obtained by PT Sierad Produce Tbk from processing chicken meat into processed chicken products amounted to $67.55 \%$. The value is a net added value of the process of processing chicken meat into processed chicken products.

\subsection{Recommendation}

Based on the conclusion of value added analysis of processed chicken products at PT Sierad Produce Tbk, the authors suggest several things as follows:

1. Fried meatball products have a low profit rate. To increase the profitability of the product, the company should reduce the amount of labor or increase the production amount of Fried Meatballs.

2. Companies should increase the production of highly processed chicken meat products, such as Chicken Nugget Ceria, Chicken Nugget S Royal, Chicken Nugget Favorite Chicken Nugget Safari, and Chicken Nugget Stick Favorite to increase profits.

\section{References}

[1] [BPS]. 2015. Konsumsi Rata-rata per Kapita Seminggu Beberapa Macam Bahan Makanan Penting 2007-2014. http://www.bps.go.id/linkTabelStatis/view/id/950 March 2016).

[2] Ali, M. 2011. Manajemen Operasi dan Produksi. UNY. Yogyakarta. Aminah. 2013. Analisis Nilai Tambah dalam Pengolahan Susu Kedelai pada Skala Industri Rumah Tangga di Kota Medan. [Bachelor Thesis]. Department of Agribusiness. Faculty of Agriculture, North Sumatera University. Medan.

[3] Hasibuan, N. F. 2007. Analisis Nilai Tambah Ayam Bakar (Studi Kasus di Rumah Makan Wong Solo Halalan Thayyiban Cabang Depok). [Bachelor Thesis]. Department of Agricultural Socio Economic. Faculty of Animal Husbandry, Bogor Agricultural University. Bogor.

[4] Isdriani, S. 2012. Analisis Nilai Tambah Jahe Merah Instan pada Industri Rumah Tangga (IRT) Enam Putri. [Bachelor Thesis]. Department of Agribusiness. Faculty of Science and Technology, Syarif Hidayatullah State Islamic University. Jakarta.

[5] Sarah, D. 2015. Analisis Nilai Tambah dan Bauran Pemasaran Produk Olahan Daging Sapi dan Daging Ayam pada CV Fivafood Meat \& Supply. [Bachelor Thesis]. Department of Agribusiness. Faculty of Science and Technology Syarif Hidayatullah State Islamic University. Jakarta.

[6] Marimin and Nurul, M. 2010. Aplikasi Teknik Pengambilan Keputusan dalam Manajemen Rantai Pasok. IPB Press. Bogor. 